\title{
Aplikasi Visualisasi Tingkat Polusi Debu Pada Udara Bebas Di Balai Pengamatan Antariksa dan Atmosfer Pasuruan Jawa Timur
}

\author{
Ivan Surya Prinnatama ${ }^{1}$, Teguh Sutanto ${ }^{2}$, Endra Rahmawati ${ }^{3}$ \\ Program Studi S1 Sistem Informasi, Universitas Dinamika \\ Email: ${ }^{1} 15410100171 @$ dinamika.ac.id, ${ }^{2}$ teguh@dinamika.ac.id, ${ }^{3}$ rahmawati@dinamika.ac.id
}

\begin{abstract}
Abstrak: Lapan Pasuruan atau Balai Pengamatan Antariksa dan Atmosfer merupakan suatu lembaga yang mengamati ruang dan atmosfer yang berada di Kabupaten Pasuruan Jawa Timur. Pemantauan tingkat pencemaran debu adalah bagian dari aktivitas mereka. Saat ini, informasi tentang tingkat polusi debu tidak dapat divisualisasikan dan disajikan bila diperlukan. Hal ini tentunya menurunkan kualitas informasi dari dimensi waktu. Informasi tentang polusi debu tidak akan berguna jika terlambat diberikan. Penerapan pemantauan tingkat pencemaran debu dapat membantu untuk membuat dan menyajikan informasi tingkat pencemaran debu serta dapat memberikan pesan peringatan dini dan menyampaikan kepada pihak yang membutuhkan melalui email apabila tingkat pencemaran debu telah melewati batas aman, sehingga dapat dilakukan pengambilan keputusan dengan segera.
\end{abstract}

Kata Kunci: Aplikasi, Visualisasi, Polusi Debu, Udara Bebas.

Abstract: Lapan Pasuruan or Balai Pengamatan Antariksa dan Atmosfer is an institution that observes space and atmosphere located in Pasuruan East java. Dust pollutions level monitoring are part of their activity. Currently, information on dust pollution levels can't be visualization and served when needed. This certainly reduces the quality of information from the time dimension. The information about dust pollution will be of no use when supplied too late. Application of dust pollution level monitoring can assist to create and present the dust pollution level information and also can give an early warning message and deliver to those who need by email when the dust pollution level past the safety limit, so decision-making can be done immediately.

Keywords: Application, Visualization, Dust Pollution, Free Air.

\section{PENDAHULUAN}

Salah satu kegiatan yang penting pada Balai Pengamatan Antariksa dan Atmosfer Pasuruan yaitu pemantauan tingkat polusi debu. Kegiatan ini dilakukan untuk mengetahui seberapa besar polusi debu yang ada di sekitar Balai Pengamatan Antariksa dan Atmosfer Pasuruan serta faktor yang mempengaruhinya seperti suhu, kelembapan, kecepatan angin serta arah angin dengan radius $5 \mathrm{~km}$. Pemantauan ini juga dimungkinkan sebagai sarana untuk mengetahui waktu yang tepat pemantauan antariksa agar tidak terganggu dengan polusi debu yang ada di udara bebas serta mengetahui tingkat kualitas udara di lingkungan sekitar.

Standart Total Suspended Particulate (T.S.P) tingkat polusi debu dapat dikategorikan menjadi 5 jenis [1]. Tingkat polusi debu dengan kategori sangat tidak sehat berada pada kisaran antara $0,376-0,625 \mathrm{mg} / \mathrm{m} 3$ dan kategori berbahaya berada pada kisaran antara > $0,625 \mathrm{mg} / \mathrm{m} 3$. Pengamatan yang dilakukan secara otomatis seperti pengamatan matahari dan atmosfer mempunyai batas < $376 \mathrm{mg} / \mathrm{m} 3$ karena debu dapat menyebabkan kerusakan serta gangguan pada alat-alat pengamatan dan sensor [2]. Debu juga dapat mengganggu aktivitas di lingkungan sekitar dan berbahaya bagi kesehatan masyarakat. Menurutnya jarak pandang, dapat memicu penyakit pernafasan seperti ispa dan asma adalah beberapa dampak dari polusi debu yang melewati batas aman. Balai Pengamatan Antariksa dan Atmosfer Pasuruan melakukan pengambilan data dilakukan per 5 menit dari jam 07.00-16.00 WIB setiap hari untuk tingkat polusi debu dan per 5 menit selama 24 jam untuk data suhu, kelembapan, kecepatan angin serta arah angin. Alat yang digunakan untuk mengukur tingkat polusi debu disebut sebagai Enviromental Particular Air Monitoring (EPAM) [3]. Alat untuk mengukur suhu, kelembapan, kecepatan angin, arah angin dan tekanan udara disebut sebagai Automatic Weather Stasion (AWS).

Data hasil perekaman AWS berbentuk file .txt yang berisikan data rekaman suhu, kelembapan, kecepatan angin, arah angin serta tekanan udara. Data hasil perekaman yang sudah tersimpan selanjutnya akan diolah menjadi suatu informasi sesuai permintaan, baik dari pihak Balai Pengamatan Antariksa dan Atmosfer Pasuruan atau pihak luar lembaga yang membutuhkan informasi.

Berdasarkan tinjauan di atas, diketahui bahwa ada masalah mengenai kualitas informasi tingkat polusi debu. Informasi tingkat polusi debu tidak dapat disajikan oleh bagian pengamat atmosfer saat dibutuhkan seperti ketika tingkat polusi debu melewati batas aman, bagian pengamatan atmosfer tidak dapat memberikan peringatan dini.

Dari permasalahan tersebut, maka diperlukan suatu aplikasi yang dapat meningkatkan kualitas 
informasi dari tingkat polusi debu. Aplikasi tersebut juga dapat digunakan sebagai sarana visualisasi terhadap data tingkat polusi debu yang lebih informatif [4]. Aplikasi juga dapat memberikan peringatan dini ketika tingkat polusi deby melewati batas aman.Penelitian ini menghasilkan sebuah aplikasi visualisasi tingkat polusi debu pada udara bebas, Aplikasi ini diharapkan mampu mempercepat proses pengolahan informasi tingkat polusi debu serta pengiriman informasi peringatan dini terhadap bahaya tingkat polusi debu, sehingga kualitas informasi peringatan dini terhadap bahaya tingkat polusi debu pada BPAA Pasuruan dapat ditingkatkan.

Faktor yang sangat mempengaruhi konsentrasi tingkat polusi debu adalah kondisi udara seperti suhu, kelembapan, kecepatan serta arah angin [5] maka kondisi ini harus dicatat dan diperhitungkan dengan menggunakan persamaan sebagai berikut:

a. Kondisi udara basah normal (kelembapan > 49\%)

$$
C N . F=C B \cdot \frac{T}{T N} \cdot \frac{P N}{P}
$$

b. Kondisi udara kering normal (Kelembapan $<50 \%$

Keterangan:

$$
C N . t r=C N \cdot F \cdot \frac{100}{100-F}
$$

$\mathrm{CN} . \mathrm{F}=$ tingkat konsentrasi partikel debu normal $\left(\mathrm{mg} / \mathrm{m}^{3}\right)$

$\mathrm{CB}=$ tingkat konsentrasi saat pengukuran $\left(\mathrm{mg} / \mathrm{m}^{3}\right)$

CN.tr = tingkat konsentrasi partikel debu saat kondisi udara kering $\left(\mathrm{mg} / \mathrm{m}^{3}\right)$

$\mathrm{T}=$ suhu udara saat pengukuran (celcius)

$\mathrm{Tn} \quad=$ suhu udara rata-rata (celcius)

$\mathrm{Pn} \quad=$ tekanan angin rata-rata (bar)

$\mathrm{P} \quad=$ tekanan angin saat pengukuran(bar)

$\mathrm{F} \quad=$ kelembapan udara saat pengukuran (\% volume).

Kelembapan yang rendah berdampak pada peningkatan polusi debu, kelembapan yang tinggi mengakibatkan penurunan tingkat polusi debu. Kecepatan angin yang tinggi menyebabkan penurunan tingkat polusi debu, kecepatan angin yang rendah berdampak pada peningkatan tingkat polusi debu. Suhu yang tinggi mengakibatkan tingkat polusi debu meningkat dan suhu yang rendah mengakibatkan penurunan tingkat polusi debu [6].

Tabel 1 Kategori tingkat polusi debu [1]

\begin{tabular}{lll}
\hline Kategori & $\begin{array}{l}\text { TSP } \\
\mathbf{m g} / \mathbf{m}^{\mathbf{3}}\end{array}$ & \multicolumn{1}{c}{ Efek } \\
\hline Baik & $\begin{array}{l}0 \text { sampai } \\
0,075\end{array}$ & Tidak ada \\
& $\begin{array}{l}0.076 \\
\text { sampai }\end{array}$ & $\begin{array}{l}\text { Penurunan jarak } \\
\text { pandang }\end{array}$ \\
& 0,26 & \\
\hline Tidak & 0.261 & Jarak pandang \\
sehat & sampai & $\begin{array}{l}\text { turun dan terjadi } \\
\text { pengotoran } \\
\text { dimana-mana }\end{array}$ \\
\hline
\end{tabular}

\begin{tabular}{lll}
\hline $\begin{array}{l}\text { Sangat } \\
\text { tidak sehat }\end{array}$ & $\begin{array}{l}0.376 \\
\text { sampai } \\
0.625\end{array}$ & $\begin{array}{l}\text { Sensitivitas } \\
\text { meningkat pada } \\
\text { pasien asma dan } \\
\text { bronkhitis }\end{array}$ \\
\hline Berbahaya & $>0,625$ & $\begin{array}{l}\text { Berbahaya bagi } \\
\text { populasi yang } \\
\text { terdampak }\end{array}$ \\
\hline
\end{tabular}

\section{METODE}

Tahapan penelitian Pembuatan Aplikasi Visualisasi Tingkat Polusi Debu ini menggunakan konsep Pengembangan Perangkat Lunak SDLC Waterfall [7]. Tahapan awal adalah Communication, Planning, Modelling, Construct, dan Deployment.

\section{Wawancara}

Wawancara dilakukan kepada Bagian Pengamat Antariksa yang dilakukan pada bulan Januari 2019 hingga bulan April 2019 sehingga terdapat kesamaan data yang diambil dengan wawancara yang dilakukan untuk menggali informasi mengenai proses pengukuran tingkat polusi debu dan proses penyajian informasi tingkat polusi debu.

\section{Observasi}

Observasi dilakukan dengan mengunjungi Balai Pengamatan Antariksa dan Atmosfir Pasuruan Jawa Timur untuk melakukan pengamatan. Pengamatan dilakukan pada bulan Januari sampai April 2019 untuk mendapatkan beberapa hal seperti :

a. Gambaran umum Balai Pengamatan Antariksa dan Atmosfir Pasuruan Jawa Timur.

b. Mempelajari Proses Pengukuran Tingkat polusi debu pada udara bebas.

c. Mempelajari proses penyajian informasi tingkat polusi debu pada udara bebas.

\section{Identifikasi Masalah}

Berdasarkan hasil observasi dan wawancara yang dilakukan pada Bagian pengamat antariksa, terdapat masalah mengenai kualitas informasi tingkat polusi debu. Informasi tingkat polusi debu tidak dapat disajikan oleh bagian pengamat ketika tingkat polusi debu melewati batas aman, bagian pengamatan atmosfer tidak dapat memberikan peringatan dini. Hal mengakibatkan penurunan kualitas informasi dari segi timeliness serta informasi yang dihasilkan menjadi tidak berguna karena tidak tersedia saat dibutuhkan.

\section{Identifikasi Data}

Data-data yang diperlukan untuk pembuatan aplikasi monitoring tingkat polusi debu pada udara bebas adalah sebagai berikut:
a. data tingkat partikel debu
b. data kondisi udara
c. data penerima pesan peringatan dini 


\section{Identifikasi Fungsi} berikut:

Fungsional aplikasi yang diperlukan sebagai

a. Pengelolaan data penerima pesan peringatan dini.

b. Pengelolaan data tingkat partikel debu dan data kondisi udara.

c. Visualisasi data.

d. Pengiriman pesan peringatan dini tingkat polusi debu melewati batas aman.

e. Pencarian data tingkat polusi debu.

f. Visualisasi data hasil pencarian data tingkat polusi debu.

g. Cetak Laporan tingkat polusi debu.

\section{Modeling}

Berdasarkan analisis sistem dari permasalahan yang dihadapi, selanjutnya akan dibuat desain dari aplikasi tersebut. Tujuan dari desain aplikasi ini adalah membuat kerangka dasar dalam melakukan implementasi ke sistem informasi yang dibuat.

Dalam perancangan sistem ini ada beberapa tahapan yang harus dilakukan, yaitu pembuatan Model Pengembangan, System Flow, Data Flow Diagram (DFD), Entity Relationship Diagram (ERD), Struktur Database, dan Desain Input dan Output dari program aplikasi ini.

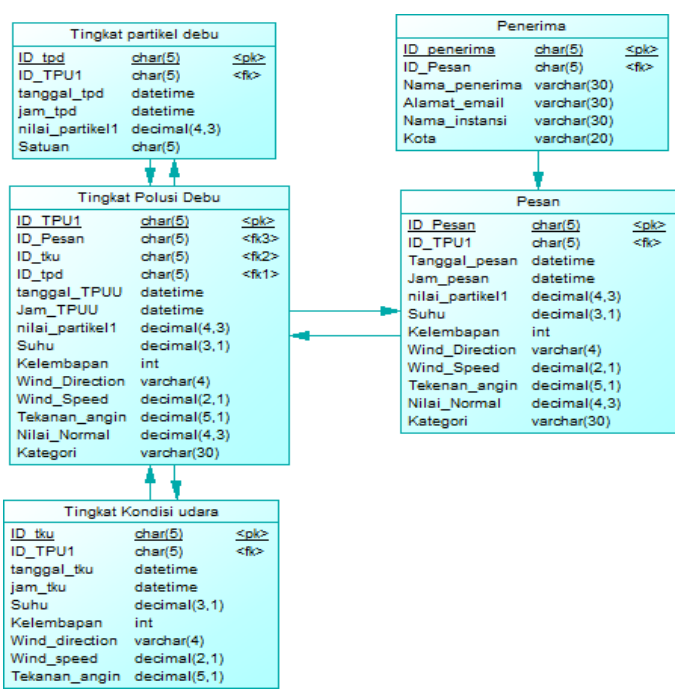

Gambar 1. Physical Data Model

\section{System Flow}

Pada proses ini data yang ada pada alat EPAM dan AWS akan disimpan ke dalam database. Selanjutnya sistem akan menampilkan data yang sudah tersimpan pada tanggal tersebut.

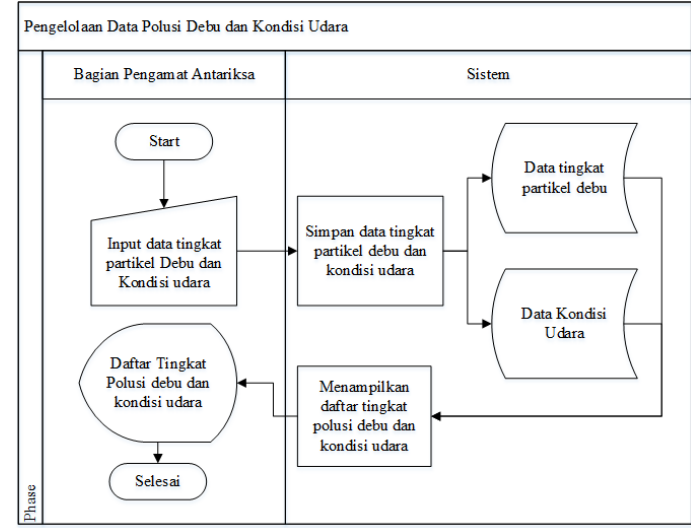

Gambar 2. Sysflow pengelolaan data

\section{Data Flow Diagram}

Data Flow Diagram di bawah ini menggambarkan menggambarkan terdapat 3 proses utama yang saling berhubungan, antara lain: pengelolaan data master, visualisasi dan perhitungan data dan cetak laporan.

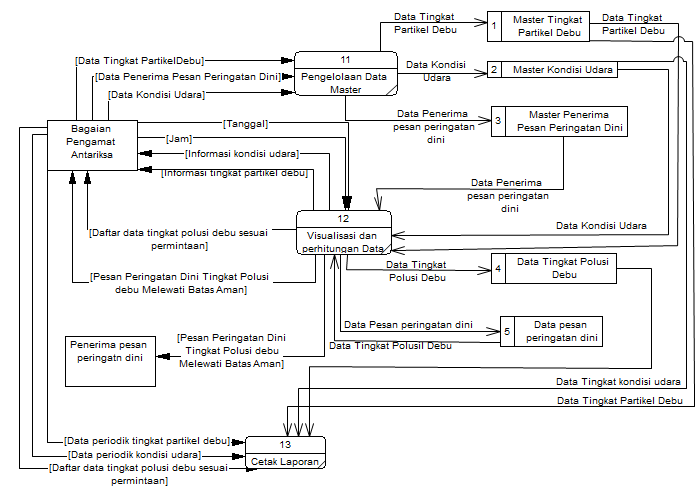

Gambar 3. DFD Level 0

\section{HASIL DAN PEMBAHASAN Tampilan Dashboard}

Form dashboard akan tampil ketika aplikasi mulai dijalankan. Pengguna dapat melihat informasi dan grafik tentang tingkat partikel debu dan kondisi udara secara real-time.

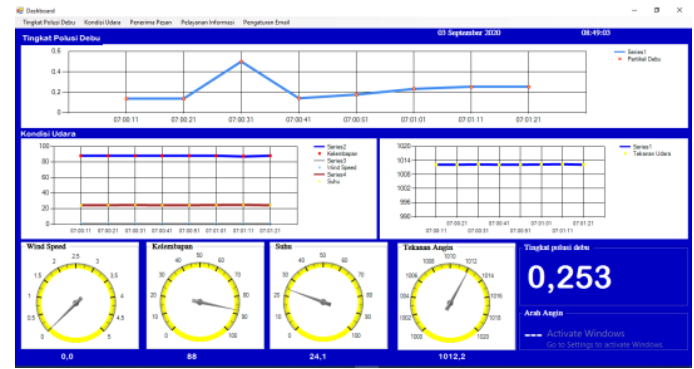

Gambar 4. Tampilan Dashboard 


\section{Tampilan Form Tingkat Partikel Debu Harian}

Form tingkat partikel debu harian akan tampil ketika pengguna memilih menu tingkat partikel debu harian pada form dashboard. Pengguna dapat melihat data, informasi serta grafik tentang tingkat partikel debu secara real-time. Di bagian nilai tingkat partikel debu akan berubah warna untuk membedakan tingkat atau kategori nilai tersebut.

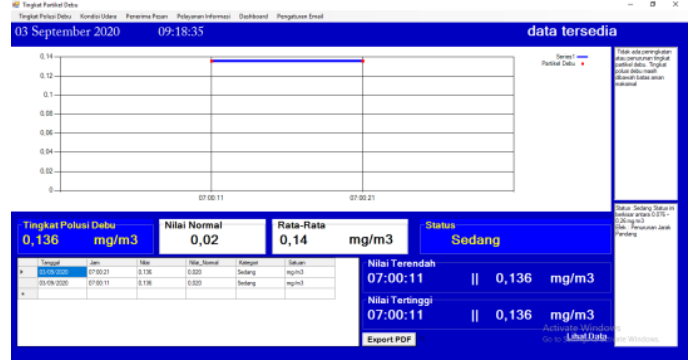

Gambar 5. Tampilan form tingkat partikel debu harian.

\section{Tampilan Form Kondisi Udara Harian}

Form kondisi udara harian akan tampil ketika pengguna memilih menu kondisi udara harian. Pengguna dapat melihat data, informasi serta grafik tentang kondisi udara harian.

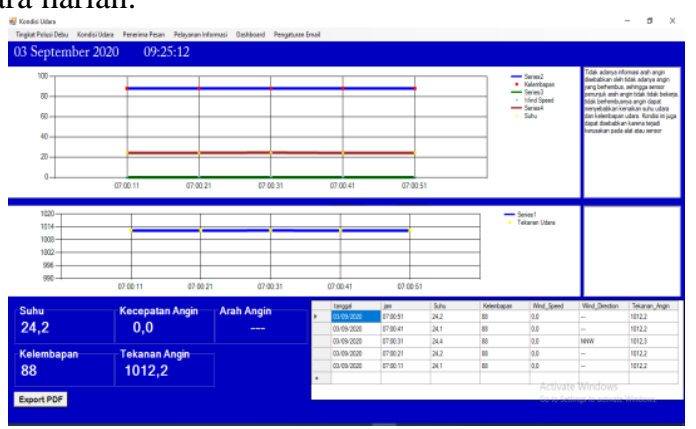

Gambar 6. Tampilan form kondisi udara harian.

\section{Tampilan Form Pengelolaan Penerima Pesan Peringatan Dini}

Form pengelolaan penerima pesan peringatan dini akan tampil ketika pengguna memilih menu pengelolaan email penerima pesan peringatan dini.

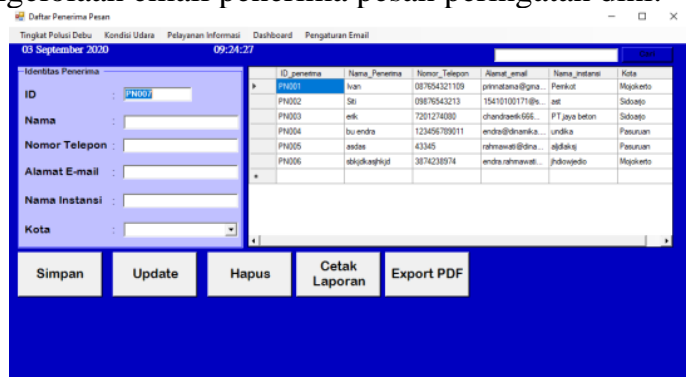

Gambar 7. Tampilan form pengelolaan penerima pesan peringatan dini.

\section{Tampilan Form Pelayanan Informasi}

Form pelayanan informasi akan tampil ketika pengguna memilih menu pelayanan informasi. Pengguna dapat melakukan pencarian terhadap data tingkat polusi debu dengan cara memasukan parameter berupa jam dan tanggal. Pada halaman ini terdapat dua menu, yaitu menu pencarian data pada jam $\mathrm{x}$ antara tanggal $\mathrm{z}$ dan tanggal $\mathrm{y}$, lalu terdapat menu pencarian data pada jam z sampai jam y pada jam x. Pada halaman ini juga tersedia tombol "grafik" yang berfungsi untuk menampilkan detil dari hasil pencarian.

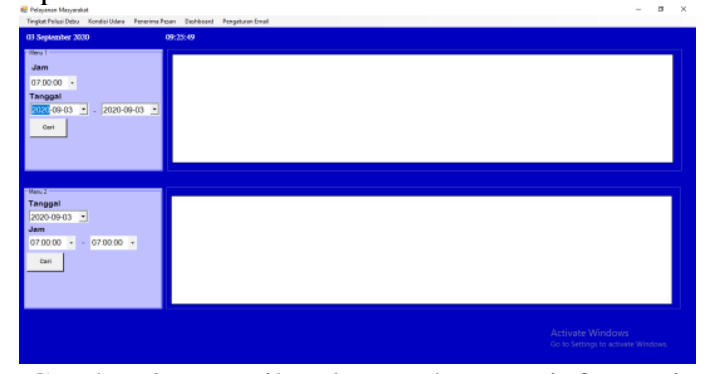

Gambar 8. Tampilan form pelayanan informasi.

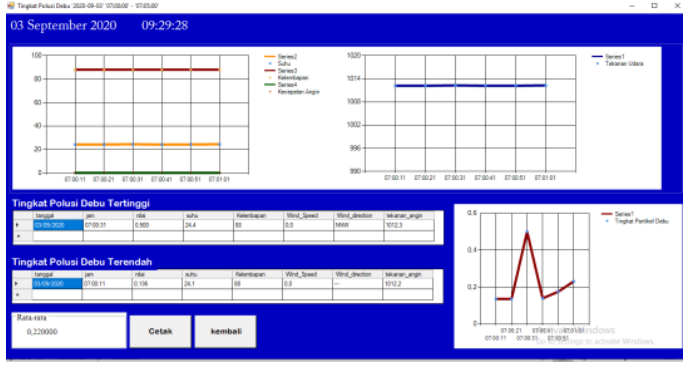

Gambar 9. Tampilan form detil pelayanan informasi.

\section{Tampilan Form Tingkat Partikel Debu Bulanan}

Form tingkat partikel debu bulanan akan tampil ketika pengguna memilih menu tingkat partikel debu bulanan pada form dashboard. Pengguna dapat melihat data, informasi serta grafik tentang tingkat partikel debu.

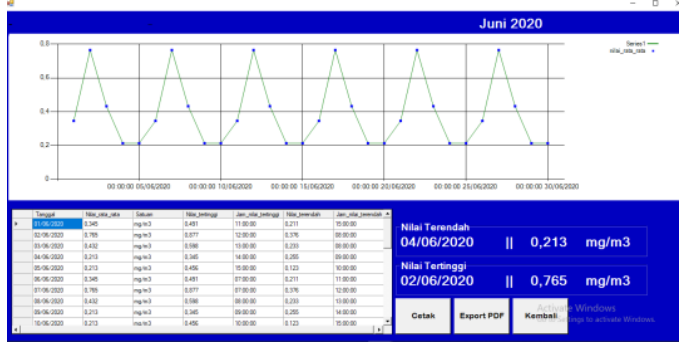

Gambar 10. Tampilan form tingkat partikel debu bulanan.

\section{Tampilan Form Tingkat Partikel Debu Tahunan}

Form tingkat partikel debu tahunan akan tampil ketika pengguna memilih menu tingkat partikel debu tahunan pada form dashboard. Pengguna dapat melihat data, informasi serta grafik tentang tingkat partikel debu. 


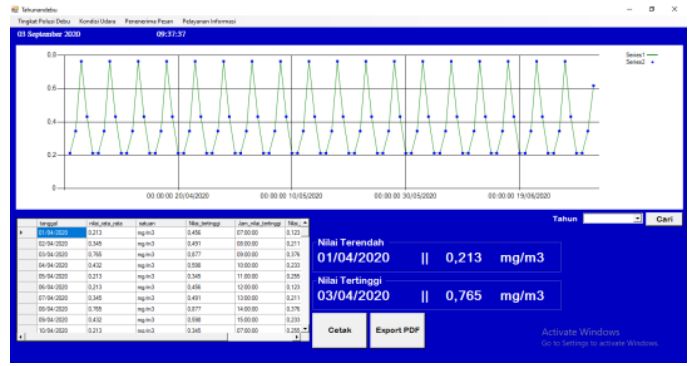

Gambar 11. Tampilan form tingkat partikel debu tahunan.

\section{Tampilan Form Kondisi Udara Bulanan}

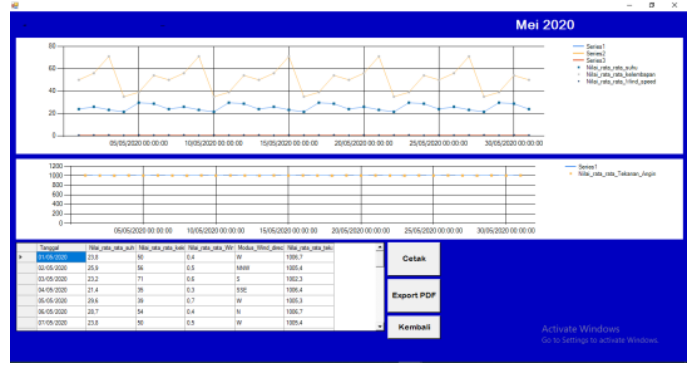

Gambar 12. Tampilan form kondisi udara bulanan.

Form kondisi udara bulanan akan tampil ketika pengguna memilih menu kondisi udara bulanan. Pengguna dapat melihat data, informasi serta grafik tentang kondisi udara harian bulanan.

\section{Tampilan Form Kondisi Udara Tahunan}

Form kondisi udara tahunan akan tampil ketika pengguna memilih menu kondisi udara tahunan. Pengguna dapat melihat data, informasi serta grafik tentang kondisi udara tahunan.

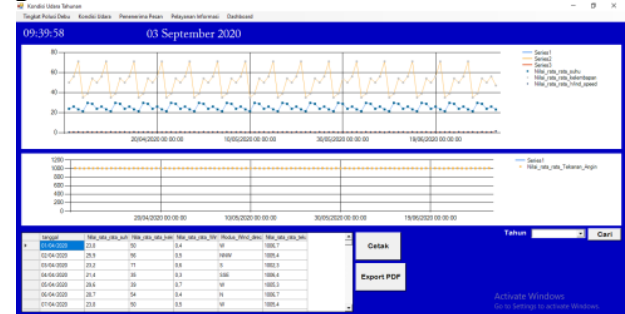

Gambar 13. Tampilan form kondisi udara tahunan.

\section{Notifikasi Email Peringatan Dini}

Untuk notifikasi atau warning tingkat polusi debu dapat dikirimkan melalui email yang telah terdaftar di aplikasi dan akan dikirim ke bagian terkait dan pihak luar yang membutuhkan informasi mengenai tingkat polusi debu.

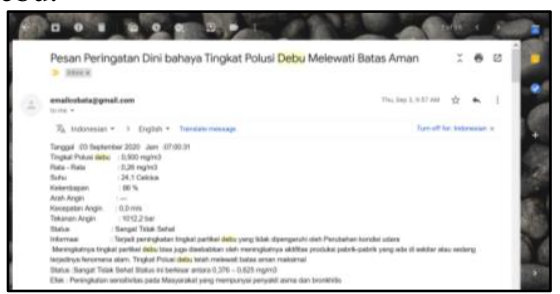

Gambar 14. Tampilan email Pesan Peringatan Dini Bahaya Tingkat Polusi Debu.

\section{KESIMPULAN}

Kesimpulan yang dapat di ambil dari aplikasi monitoring tingkat polusi debu pada udara bebas di Balai Pengamatan Antariksa Dan Atmosfer Pasuruan Jawa Timur sebagai berikut:

1. Aplikasi dapat mengumpulkan data hasil rekaman tingkat partikel debu dan kondisi udara, selanjutnya data yang sudah terkumpul akan di proses seperti menentukan kategori tingkat partikel debu, menghitung nilai normal tingkat partikel debu, menghitung nilai rata-rata dan menentukan nilai terbesar dan nilai terkecil tingkat partikel debu dan kondisi udara.

2. Aplikasi akan mengkomunikasikan hasil dari pengumpulan data dan proses perhitungan dengan menampilkan grafik tingkat partikel debu dan kondisi udara, data tingkat partikel debu dan kondisi udara, hasil proses perhitungan.

3. Aplikasi ini dapat meningkatkan kualitas informasi tingkat polusi debu pada udara bebas yang melewati batas aman dari segi timeliness karena informasi tingkat polusi debu dan peringatan dini tingkat polusi debu melewati batas aman disajikan secara langsung melalui email.

\section{SARAN}

Aplikasi monitoring tingkat polusi debu pada udara bebas di Balai Pengamatan Antariksa Dan Atmosfer Pasuruan Jawa Timur ini masih memiliki kekurangan. Adapun saran yang dapat disampaikan kepada peneliti berikutnya adalah sebagai berikut :

1. Penambahan fitur peramalan tingkat polusi debu.

2. Tersedianya aplikasi dalam bentuk web atau mobile apps.

3. Penambahan fitur yang dapat meningkatkan lagi kualitas informasi tingkat polusi debu pada udara bebas baik dari dimensi konten atau dimensi bentuk.

\section{Ucapan Terimakasih}

Terimakasih disampaikan pada pihak-pihak yang membantu dalam mendukung penyelesaian penelitian ini yaitu Universitas Dinamika dan Balai Pengamatan Antariksa Dan Atmosfer Pasuruan Jawa Timur.

\section{DAFTAR PUSTAKA}

[1] Airpollution, "Partikulat (PM 2.5, PM 10, TSP)," 2014. [Online]. Available:

https://airpollution2014.weebly.com/dampakpencemaran-udara---partikulat/partikulat-pm-25pm-10-tsp. [Accessed 19 Agustus 2019].

[2] A. Widianjaya, R. N. Handoko, D. Firmanda, A. Y. Ardiansyah and R. W. Pradita, "“Green Map" Sistem Monitoring Dan Peta Visualisasi Distribusi Kualitas Udara Berbasis Web," in Pekan Ilmiah Mahasiswa Nasional Program Kreativitas 
Mahasiswa- Karsa Cipta 2014 (PIMNAS PKM$K C)$, Jakarta, 2014.

[3] E. D. Corporation, "EPAM-5000 Enviromental Particulate AirMonitoring," 2019. [Online]. Available: https://environmentaldevices.com/epam-5000/. [Accessed 19 Agustus 2019].

[4] N. Arminarahmah, M. Rasyidan and Z. , "Desain Dan Implementasipengukur Kualitas Udara Pm10 Berbasis Mikrokontroller," JTIULM, vol. 2, no. 1, hal. 31-37, Juni 2017.

[5] G. Suhariyono, M. Saeni and A. Bey, "Analisis Tingkat Bahaya Partikel Debu Pm10 dan Pm25 Terhadap Kesehatan Penduduk Di Sekitar Pabrik Semen Citeureup Bogor," in Prosiding Pertemuan dan Presentasi Ilmiah Penelitian Dasar Ilmu Pengetahuan dan Teknologi Nuklir, P3TMBATAN Yogyakarta, 8 Juli 2003.

[6] K. Aisyiah, S. and I. N. Latra, "Pemodelan Konsentrasi Partikel Debu (PM10)pada Pencemaran Udara di Kota Surabaya dengan Metode Geographically-Temporally Weighted Regression," Jurnal Sains Dan Seni Pomits 2337. 3520(2301-928X Print), vol. 2, no. 1, 2014.

[7] R. Pressman, Rekayasa Perangkat Lunak: Pendekatan Praktisi Buku 1, Yogyakarta: ANDI, 2015. 